\title{
Evaluation the Level of Dieldrin and Heptachlor in Iraqi People
}

\author{
Alaa H. Jawad \\ Department of Chemistry, College of Science, Al-Nahrain University, Baghdad-Iraq. \\ Corresponding Author: Alaaalqaisi74@yahoo.com.
}

\begin{abstract}
Organochlorine pesticides for whatever length of time that been extensively utilized as a part of farming and in public health as highly effective pest control agents.

They are lipophelic and have drawn out a half-existences of years to decades; thus, they amass in human fat tessues and a can bring about endless poisonous quality after long term exposure.

To detect and measure the concentrations of organochlorine pesticides, (Dieldrin and Heptachlor) in serum and fatty tissue samples and studies their correlation with lipids in order to reveal the need. for human monitoring.

The study was conducted on 50 samples of blood and fatty tissues to determine their lipid concentrations and detect metabolites of organochlorine pesticides and asses theirlcorrelations using HPLC.

The study observed that there were raised serum concentrations of lipids which were positively corresponded with lifted serum convergences of Dieldrin and Heptachlor pesticides.

Mean serum concentrations of triglycerides was inside "normal" range while mean serum of aggregate cholesterol was hoisted above ordinary range. Rate of grouping of lipid to serum Dieldrin was higher than that of Heptachlor in living subjects. [DOI: 10.22401/JNUS.20.3.05]
\end{abstract}

Keywords: Dieldrin, Heptachlor, Pesticides.

\section{Introduction}

Pesticides characterized as any substance or blend of materials proposed for devastating, anticipating, adjusting and opposing to some degree nuisance, or substances managed to creatures for the controlling creepy crawlies, 8-legged creature or different irritations. A pesticide might be a natural operator, disinfectant, antimicrobial, concoction substance or gadget used to battle any irritation $^{(1)}$. Organochlorine pesticides are classes of hydrocarbon mixes described by their cyclic structure, number and area of chlorine molecules and low unpredictability. They were broadly utilized as a part of agribusiness and for irritation control after they were presented in the $1940 \mathrm{~s}^{(2)}$.

Organochlorine segments have o low levels in the earth .They are framed normally .Many of a their uses have been invalid or limited since a their biological diligence and potential unfriendly embellishments on common environment and social health ${ }^{(3)}$.

Organochlorine compound is a fat-loving and is expected to be a vital compound in the human body and can be found in human adipose tissue, draining the bosom and bloods. Organic chlorine levels, the substances generally are almost the same in different body tissues after less in the blood ${ }^{(4)}$.

Measurable levels of organochlorine pesticides have begun in human lipid plasma tissue and incubation drain across the world ${ }^{(5)}$.

Chlordane, a human-made substance mixture basically like organochlorines was broadly utilized on, agrarian harvests and as a disinfectant in the United States of America until 1988. Chlordane is made up of > 140 most abundant isomers incorporating chlordane transition, CIS chlordane, trans. nonaclur, betachlordane and heptachlor ${ }^{(6)}$.

In people the prevalent chlordane related contaminants distinguished are transnonachlor and oxychlordane. (significant metabolites of the chlordane). Chlordane's have a 10-to 20-year5 half-life in soil ${ }^{(7)}$.

Chlordane square inhibitory; neurotransmitters and result in focal sensory system poisonous quality and when intense high measurements are taken seizures and loss of motion happen. Chlordane perhapse cancercausing to people ${ }^{(8)}$.

McGlynn et al. discovered $n$ huge relationship between hazard of testicular germ cell tumors and serum levelsofcis-nonachlor, trans-nonachlor, and add up to chlordanes. 
A comparative study of the symposium revealed a critical relationship between seminoma and cis-nonaclour levels, transnocalore, oxyclordane, and adds up to chlordanes $^{(9,10)}$.

\section{Materials and Methods}

Fifty patients undergoing any surgical operation were included in the study after their written consent .They was undergoing surgical operations in Al-Imamain Al-Kadmin Teaching hospital. $10 \mathrm{ml}$ of Blood and $5 \mathrm{~g}$ of fatty tissue Samples were collected from each patient and stored in the freezer at $4^{\circ} \mathrm{C}$ for blood samples and $-8^{\circ} \mathrm{C}$ for fatty tissue samples. Each specimen was sent for a substance investigation at the Department of Chemistry and Biochemistry lab. Montage of Science, University of Al-Nahrain to decide lipide profile and to quantify the level of Organochlorinea pesticide paying little respect to their: age and sex.

Blood samples were $\mathrm{s}$ separated by $3000 \mathrm{rpm}$ a fast centrifuge for 15 minutes, and the serum was collected and divided into two $\mathrm{m}$ equal parts, first one for lipid profile a test and the other one for a checking organochlorine pesticides.

\section{Organochlorine pesticides.}

two hundred $\mu 1$ of serum added to $25 \mu \mathrm{l}$ of salicylic corrosive $25 \%$ to serum deproteinzation an and centrifugation in a rotator s for 10 minutes and e at long last took $20 \mu \mathrm{l}$ of arranged specimen and infusion of elite; fluid chromatography.

\section{(HPLC)}

\section{lipid profile}

Proceduree of measure of cholesterole \& Triglyceride in a samples:-

1. One ml was included from y(cholesterole or Triglyceridee) in the test tube.

2. Ten $\mu$ l was included from serum in the samee test tube.

3. The blend was shaken for couple of minutes.

4. The tube was placed in the water, way for 51 minutes undere, condition $37 \mathrm{c}$.

5. Absorption was, read by a spectrophotometer, at wave length $(510 \mathrm{~nm}$ CHOL) and (505nm TG).

\section{Extraction of tissue}

The extract one gram of fat tissue using $n$ hexane, resolve to dissolve tissue homogenizer homogeneity by adding $1 \mathrm{ml}$ of the same solution to become a 3: 1 and continued homogeneity of the sample to become a solution homogeneity. The solution homogeneity expelled, by centrifugation for 10 min. The sample was centrifuged and separated into two layers, and took the top of the sample is injected for HPLC ${ }^{(11,12)}$.

\section{Measured concentration in total lipid}

The aggregate lipids balanced convergence of the pesticide obtained by partitioning the deliberate pesticides a buildup fixation in the aggregate tissue test by thee decimal a small amount of thee example that comprised of ether-extractablee lipid. The totale lipid rating of each example of itis adds up to cholesterol and triglyceride levels by using the summation method. The analysis of chlorine organic pesticides has been calculated on a balanced fat hypothesis (ng per gram or parts per billion) ${ }^{(14)}$.

\section{Results}

Fifty patients undergoing any surgical operation were engaged in the study. Females were 28 constituting $57.5 \%$ while males were 22 that were $42.5 \%$. The mean age was $36 \pm 10.21$ years.

Mean serum concentrations of triglycerides was elevated above normal range while mean, serum of the total cholesteroll was within normal ranges as in Table (1) (n1e).

Table (1)

Mean, SD and range of age and lipid parameters.

\begin{tabular}{||c||c||c||}
\hline Range & Mean & Parameters \\
\hline \hline $20-65$ & $37 \pm 11.31$ & Age (yrs.) \\
\hline \hline $72-358$ & $153.75 \pm 41.71$ & Serum Triglyceride \\
\hline $162.8-268.3$ & $209.89 \pm 26.11$ & Serum Cholesterol. \\
\hline \hline $571.96-857.34$ & $692.49 \pm 74.54$ & Total lipid \\
\hline
\end{tabular}

The means for Dieldrin in serum and in tissue were higher than that for Heptachlor. There were significant differences between their concentrations in serum and tissue as listed in Table (2) and shown in Fig.(1). 
Table (2)

The difference in serum and tissues in Dieldrin and Heptachlor.

\begin{tabular}{|c||c|c||c||}
\hline $\boldsymbol{P}$ value & $\begin{array}{c}\text { Tissue } \\
\text { mean } \pm \text { SD }\end{array}$ & $\begin{array}{c}\text { Serum } \\
\text { mean } \pm \text { SD }\end{array}$ & Parameters \\
\hline \hline$<0.001$ & $4.22 \pm 0.45$ & $1.73 \pm 0.17$ & Dieldrin $(\mu \mathrm{g} / \mathrm{ml})$ \\
\hline \hline$<0.001$ & $1.24 \pm 0.08$ & $1.03 \pm 0.48$ & Heptachlor $(\mu \mathrm{g} / \mathrm{ml})$ \\
\hline
\end{tabular}

$\%$ of concentration of serum and lipid trans-chlordane was $(41.39 \pm 8.2)$ higher than that of oxychlordane $29.53 \pm 10.14$ as listed in Table (3).

Table (3)

Percentage of serum to lipid organochlorines.

\begin{tabular}{|c||c|c|}
\hline Percentage of serum to lipid & Mean \pm SD & Range \\
\hline \hline Dieldrin & $41.39 \pm 8.2$ & $29.48-60.89$ \\
\hline Heptachlor & $29.53 \pm 10.14$ & $8.24-49.14$ \\
\hline
\end{tabular}

There were no significant differences between male and female regarding different compounds in the study as shown in table down.

Table (4)

The difference in parameters between females and males.

\begin{tabular}{||c|c||c||c||}
\hline $\boldsymbol{P}$ value & $\begin{array}{c}\text { Males } \\
(\mathbf{n}=\mathbf{2 3}) \\
\text { mean } \pm \text { SD }\end{array}$ & $\begin{array}{c}\text { Females } \\
(\mathbf{n}=\mathbf{1 7}) \\
\text { mean } \pm \text { SD }\end{array}$ & Parameters \\
\hline \hline 0.978 & $36.94+12.23$ & $37.04+10.86$ & Age $(\mathrm{yrs}$. $)$ \\
\hline \hline 0.695 & $150.51+50.44$ & $156.14+34.93$ & Triglyceride $(\mathrm{mg} / \mathrm{dL})$ \\
\hline 0.488 & $206.44+27.97$ & $212.43+24.98$ & Cholesterol $(\mathrm{mg} / \mathrm{dL})$ \\
\hline 0.348 & $1.61+0.22$ & $1.67+0.16$ & Serum Dieldrin $(\mu \mathrm{g} / \mathrm{ml})$ \\
\hline 0.847 & $0.8+0.52$ & $0.77+0.52$ & Serum Heptachlor $(\mu \mathrm{g} / \mathrm{ml})$ \\
\hline 0.645 & $4.34+0.44$ & $4.4+0.27$ & Tissue Dieldrin $(\mu \mathrm{g} / \mathrm{ml})$ \\
\hline 0.549 & $1.14+0.09$ & $1.12+0.09$ & Tissue Heptachlor $(\mu \mathrm{g} / \mathrm{ml})$ \\
\hline 0.431 & $681.43+77.35$ & $700.67+73.03$ & Total lipid \\
\hline 0.364 & $41.52+7.47$ & $39.36+7.2$ & $\begin{array}{c}\text { Percentage of conc. of serum to } \\
\text { lipid (Dieldrin) }\end{array}$ \\
\hline 0.800 & $28.99+13.07$ & $27.99+10.93$ & $\begin{array}{c}\text { Percentage of conc. of serum to } \\
\text { lipid }(\text { Heptachlor })\end{array}$ \\
\hline \hline
\end{tabular}

The co-coefficient was non-significant values as listed Table (5). 
Table (5)

Relationship between age with other parameters in antemortem.

\begin{tabular}{|c||c|c|}
\hline \multicolumn{1}{|c||}{} & $\mathbf{R}$ & Parameters \\
\hline \hline 0.603 & -0.085 & Tri $(\mathrm{mg} / \mathrm{dL})$ \\
\hline 0.296 & 0.170 & Cholesterol $(\mathrm{mg} / \mathrm{dL})$ \\
\hline 0.955 & 0.009 & Serum Dieldrin $(\mathrm{mg} / \mathrm{Ml})$ \\
\hline 0.535 & 0.101 & Serum Heptachlor $(\mathrm{mg} / \mathrm{Ml})$ \\
\hline \hline 0.272 & 0.178 & Tissue Dieldrin $(\mathrm{mg} / \mathrm{Ml})$ \\
\hline \hline 0.773 & -0.047 & Tissue Heptachlor $(\mathrm{mg} / \mathrm{Ml})$ \\
\hline \hline 0.592 & 0.087 & Total lepid \\
\hline 0.994 & 0.001 & $\begin{array}{c}\text { percentage of conc. of serum } \\
\text { to lipid (Dieldrin) }\end{array}$ \\
\hline \hline 0.410 & -0.134 & $\begin{array}{c}\text { percentage of conc. of serum } \\
\text { to lipid (Heptachlor) }\end{array}$ \\
\hline
\end{tabular}

There were significant positive and negative correlation between serum concentrations of Dieldrin and Heptachlor and their serum triglyceride and cholesterol as listed in Table (6).

Table (6)

Relationship between serum and tissue Dieldrin and Heptachlor in antemortem with serum triglyceride and cholesterol.

\begin{tabular}{|c|c||c|c||c||}
\hline \multicolumn{2}{|c|}{ Serum cholesterol } & \multicolumn{2}{c|}{ Serum triglyceride } & \\
\hline $\mathbf{R}$ & $\mathbf{P}$ & $\mathbf{R}$ & $\mathbf{P}$ & Parameters \\
\hline \hline 0.039 & 0.810 & -0.063 & 0.699 & Serum Dieldrin and $(\mathrm{mg} / \mathrm{ml})$ \\
\hline 0.128 & 0.430 & 0.126 & 0.440 & Serum Heptachlor $(\mathrm{mg} / \mathrm{ml})$ \\
\hline-0.069 & 0.673 & -0.296 & 0.063 & Tissue Dieldrin $(\mathrm{mg} / \mathrm{ml})$ \\
\hline \hline-0.028 & 0.863 & -0.183 & 0.258 & Tissue Heptachlor $(\mathrm{mg} / \mathrm{ml})$ \\
\hline
\end{tabular}

\section{Discussion}

The point of this review was to measured groupings of organochlorine, in human fat tissue and serum tests. From individual's fat tissue in Iraq and evaluate some purpose behind their occasion and potential prosperity risks in perspective of the results. This is the principal complete investigation of human fat tissue and serum in the Iraq. The review was to confirm the theory that levels of the different lipid segments (add up to cholesterol and triglycerides) are differentially connected with convergences of Dieldr in and Heptachlor Since levels of chlorinated pesticides change in a direct degree to blood lipid levels.

Estimation of cholesterol and triglycerides in the serum from a similar delineation used to play out the testing stipends count of aggregate lipid levele. The chlorinated pesticides fixations can then be passed on as nanoe-gram per gram $(\mu \mathrm{g} / \mathrm{ml})$ lipid $^{(15)}$. Serum and fat greasy tissue tests were additionally acquired from (50) antemortem cases who were not on any lipid-bringing down medicine and were investigated for Dieldrin, Heptachlor, add up to cholesterol and triglyceride focuses. Relationship between toxicant fixations and lipid levels were resolved utilizing different straight relapse investigation. The review watched that hoisted serum centralizations of lipids were decidedly connected with raised serum groupings of Dieldrin and Heptachlor pesticides in examinations balanced for age and sex. The mean serum centralizations of triglycerides (153.75) was inside "customary" accomplishes (triglycerides $<200 \mathrm{mg} / \mathrm{ml}$ ) while 
mean serum of the aggregate cholesteroli (209.89) which was lifted above normali range (120-200 $\mathrm{mg} / \mathrm{ml})$. Statures in levelst of Dieldrin and Heptachlor were related with lifted levels of serum lipids. Since lifted serum lipids are an indispensable hazard computes for cardiovascular $\mathrm{x}$ sicknesses, the past affiliation, a if causal, may effectsly influences human prosperity ${ }^{(16)}$. The most grounded relationship in antemortem cases were seen for Dieldrin contrasted and Heptachlor. There were noteworthy positive and negative relationship between's serum groupings of Dieldrin and Heptachlor and their serum triglyceride and cholesterol. Positive and measurably noteworthy connections were seen between fat tissue and serum centralizations of Dieldrin and Heptachlor however not of the staying industrious natural contaminations, affirming reports that serum or plasma fixations may not give a precise representation of focuses in fat tissue in all circumstances (17). Investigates connections amongst's serum and fat tissue fixations run from negative qualities to coefficients over $0.8^{(18)}$ Information stays constrained on connections amongst serum and fat tissue convergences of determined natural toxins ${ }^{(19)}$. Fixations in the two lattices have diverse natural implications: fat tissue levels have been turned out to be a decent pointer of cumulated long haul introduction, though serum levels are viewed as a measure of current presentation and the activation of persevering natural contaminations from greasy tissues ${ }^{(20)}$.

\section{Conclusion}

* The review measured hints of organochlorines (Dieldrin and Heptachlor) were perceived in human serum and tissue demonstrating the nearness of human contamination.

* There is an appositive relationship between's both Dieldrin and Heptachlor with lipid profile (Cholesterol \&Triglyceride).

* The convergences of Dieldrin were higher than Heptachlor in the examples of the review.

\section{References}

[1] Zacharia and Tano J. Identity Physical and Chemical Properties of Pesticides, University of Dar es Salaam, Dar es Salaam University College of Education Tanzania 2014.

[2] Xiaohui Xu, Amy B. Dailey, Evelyn O, Talbott VA. Ilacqua, Greg Kearney, and Nabih R. Asal; Associations of Serum Concentrations of Organochlorine Pesticides with Breast Cancer and Prostate Cancer in U.S. Adults. Environmental Health Perspectives. (1): 118, 2012.

[3] _Nicolopoulou SP and Pitsos M. The impact of endocrine disrupters on the female reproductive system. Human reproduction Update. 7(3): 323-330, 2010.

[4] Petreas M, Smith D, Hurley S, Jeffrey S, Gilliss D and Reynolds P. Distribution of persistent, lipid soluble chemicals in breast and abdominal adipose tissues: lessons learned from a breast cancer study. Cancer Epidemiol Biomarkers Prev. 3(3): 416-424, 2014.

[5] Arzi A, Hemmati AA, Nazari Khorasgani Z. Determination and comparison of the organochlorine pesticide residue levels among benni fish of Shadegan, Mahshahr and Susangerd cities, khozestan province in Iran Jundishapur. Journal of Natural Pharmaceutical Products,6(1): 24-31, 2011.

[6] Trabert B, Longnecker MP, Brock JW. Maternal pregnancy levels of transnonachlor and oxychlordane and prevalence of cryptorchidism and hypospadias in boys. Environ Health Perspect. 120(3):478-482, 2012.

[7] Alexander J, Auðunsson GA, Benford D, Cockburn A. Chlordane as undesirable substance in animal feed Scientific Panel on Contaminants in the Food Chain. The EFSA Journal. 582: 2-53, 2011.

[8] The $4^{\text {th }}$ National Report on Human Exposure to Environmental Chemicals USA. CDC and Prevention, 2009.

[9] Purdue et al. 2006, Agency for Toxic Substances and Disease Registry Division of Toxicology and Environmental Medicine Atlanta, GA 30333 December 2013 ADDENDUM TO THE TOXICOLOGICAL PROFILE FOR CHLORDANE. 
[10] McGlynn KA, Quraishi SM, Graubard BI. Persistent organochlorine pesticides and risk of testicular germ cell tumors. Journal of Natl Cancer Inst. 100(9): 663671,2008

[11] Martinez V, Moreno JL, Garrido FA, Olea-Serrano F, Olea N. Determination of endocrine-disrupting pesticides and polychlorinated biphenyls in human serum by GC-ECD and GC-MS-MS and evaluation of contributions to the uncertainty of the results. Anal. Bioanal. Chem. 372, 765-766, 2012.

[12] Moreno-Frias, Jimenez M, Garrido FA, Martinez VJL. Olea-Serrano F \& Olea N. Determination of organochlorine compounds in human biological samples by GC-MS/MS. Journal of Biomed Chromatogr. 18: 102-111, 2004.

[13] George L, Norman R.HPLC methods for pharmaceutical analysis. Fourth edition, by Academic Press, New York. P.637, 2007.

[14] Rivas A, Fernandez MF, Cerrillo I, Ibarluzea J, Olea-Serrano MF, Pedraza V, Olea N. Human exposure to endocrine disrupters: standardization of a marker of estrogenic exposure in adipose tissue. Journal of Acta Pathol. Microbiol. Immunol. 109:185-197, 2001.

[15] Patterson DG, Needham LL, Pirkle JL, Roberts DW. Correlation between serum and adipose tissue levels of 2,3,7,8Tetrachlorodibenzo-p-dioxin in 50 persons from Missouri. Arch Environ Contam Toxicol, 17:139-143, 1988.

[16] Codru N, Schymura MJ, Negoita S. Diabetes in relation to serum levels of polychlorinated biphenyls and chlorinated pesticides in adult Native Americans. Environ Health Perspect. 115(10): 1442-7, 2007.

[17] Rollin, H.B., Sandanger, T.M., Hansen, L., Channa, K., Odland, J.O., Concentration of selected persistent organic pollutants in blood from delivering women in South Africa. Sci. Total Environ. 408, 146-152, 2009.

[18] Gaskins, A.J., Schisterman, E.F. The effect of lipid adjustment on the analysis of environmental contaminants and the outcome of human health risks. Methods Mol. Biol. 580, 371-381, 2009.
[19] Crinnion, W.J. Chlorinated pesticides: threats to health and importance of detection. Altern. Med. Rev. 14, 347-349, 2014.

[20] Arrebola, J.P., Mutch, E., Rivero, M., Choque, A., Silvestre, S., Olea, N., OcañaRiola, R., Mercado, L.A. Contribution of sociodemographic characteristics, occupation, diet and lifestyle to DDT and DDE concentrations in serum and adipose tissue from a Bolivian cohort. Environ. Int. 38, 54-61, 2012. 